
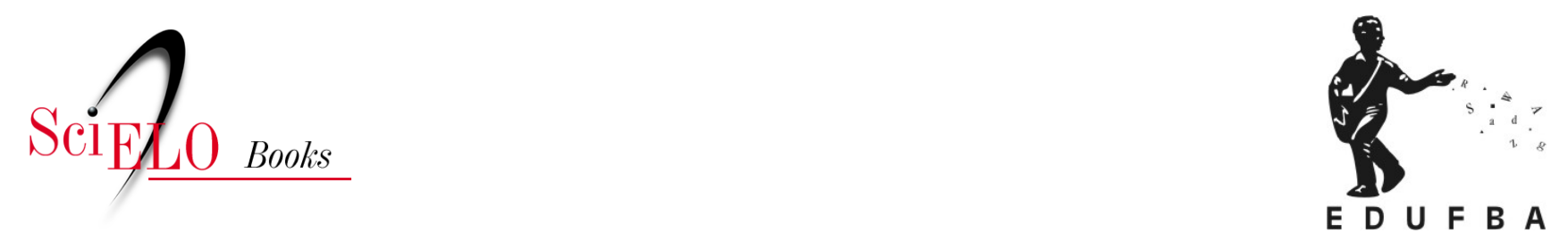

\title{
Uma reflexão sobre desenvolvimento humano na produção das ciências sociais no Brasil
}

\author{
Cristiana Mercuri
}

\section{SciELO Books / SciELO Livros / SciELO Libros}

MERCURI, C. Uma reflexão sobre desenvolvimento humano na produção das ciências sociais no Brasil. In: IVO, A.B.L., ed. A reinvenção do desenvolvimento: agências multilaterais e produção sociológica [online]. Salvador: EDUFBA, 2016, pp. 195-228. ISBN: 978-85-232-1857-7. https://doi.org/10.7476/9788523218577.0006.

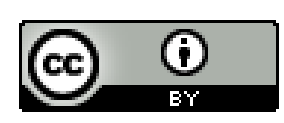

All the contents of this work, except where otherwise noted, is licensed under a Creative Commons Attribution $\underline{4.0 \text { International license. }}$

Todo o conteúdo deste trabalho, exceto quando houver ressalva, é publicado sob a licença Creative Commons Atribição 4.0. 


\title{
UMA REFLEXÃO SOBRE DESENVOLVIMENTO HUMANO NA PRODUÇÃO DAS CIÊNCIAS SOCIAIS NO BRASIL
}

\author{
Cristiana Mercuri
}

O conceito de desenvolvimento humano, desde 1990, foi adotado pela Organização das Nações Unidas (ONU) sob o argumento de promover a ampliação das análises de condições de vida, possibilitando, assim, um avanço em relação à visão economicista, por incluir os indicadores relativos à saúde e à educação, além da renda, como fundamentos do Índice de Desenvolvimento Humano (IDH) e dos Relatórios de Desenvolvimento Humano $(\mathrm{RDH})$ publicados anualmente pelo Programa das Nações Unidas para o Desenvolvimento (PNUD). Entretanto, vale lembrar com Machado e Pamplona (2008, p. 54-55) "[...] que não se trata de sinônimos [...] o IDH captura somente uma pequena parte do desenvolvimento humano, que é muito mais amplo e complexo que seu índice."

Ao adotar como referência a relevância do conceito de desenvolvimento humano, esta investigação exploratória pretende tecer algumas considerações sobre a presença desse conceito na produção 
das Ciências Sociais contemporâneas, publicada no Brasil, com base no levantamento dos usos mobilizados nos textos selecionados. Nesse sentido, distante de um caráter exaustivo ou mesmo de um mergulho mais profundo em um debate consideravelmente extenso, o propósito restringe-se à sistematização, de caráter mais descritivo, de alguns dos usos do termo desenvolvimento humano e a apresentação de algumas observações e questões sobre os usos encontrados. Foram tomadas como referências a síntese do debate sobre desenvolvimento aqui explicitada, algumas das indicações hauridas das análises de Bourdieu (1983, 2001a) sobre os campos científicos e as próprias reflexões suscitadas durante leituras dos artigos que são objeto desta investigação, os quais acentuaram ainda mais a percepção dos limites deste trabalho, ao tempo em que instituíram novas fronteiras para futuras iniciativas de pesquisa. importante ressaltar que este estudo integra uma pesquisa mais ampla dedicada a identificar e analisar a presença das agências da ONU na produção sociológica brasileira na atualidade. ${ }^{1}$

Como já foi antecipado, buscando a articulação de algumas das dimensões relativas à revisão bibliográfica que fundamenta esta reflexão, adotamos como ponto de partida a apresentação do debate mais geral sobre desenvolvimento. Nesse sentido, o objetivo foi resgatar, mesmo que em grandes traços, a história do embate de posições, alcançando alguns dos dilemas do paradigma do desenvolvimento humano em uma breve exposição com notas críticas, com destaque para a presença dos discursos e formulações das agências da ONU em relação ao tema. Tais dilemas, indissociavelmente, constituem expressões da história e do debate da própria produção das Ciências Sociais, publicada no Brasil. A esse escopo acrescentamos algumas breves referências das análises de Pierre Bourdieu sobre os campos científicos, as quais instigam as reflexões sobre a investigação exploratória que constitui a base empírica deste estudo.

Mais especificamente, partimos da seleção de revistas científicas brasileiras classificadas no extrato $\mathrm{A} 1$ pela área da Sociologia, na avaliação da Coordenação de Aperfeiçoamento de Pessoal de Nível Superior (CAPES) no ano de 2014, exclusivamente das secções Dos- 
siê e Artigos dos periódicos selecionados e publicados entre 2014 e 2016, em suas versões on-line. ${ }^{2}$ Já com base nesse conjunto de textos, foi feito um levantamento para a identificação dos artigos nos quais a expressão desenvolvimento humano é utilizada. Resumidamente, este trabalho se apresenta como um breve exercício reflexivo dedicado a levantar algumas questões sobre os usos da noção de desenvolvimento humano.

Em sequência à primeira seção, que se configura como a introdução a este trabalho, na segunda seção, intitulada "Sobre desenvolvimento e desenvolvimento humano", resgatamos a trajetória do debate sobre o tema e apresentamos, resumidamente, as concepções do PNUD e de Amartya Sen, além de algumas notas críticas sobre a temática. A terceira seção, denominada "Sobre o desenvolvimento humano na produção das Ciências Sociais", volta-se para a sistematização dos usos do termo desenvolvimento humano nos textos selecionados e para as reflexões decorrentes das análises. Na seção conclusiva, tecemos algumas considerações sobre os limites do trabalho e apontamos possíveis caminhos para o aprofundamento do tema.

\section{Sobre desenvolvimento e desenvolvimento humano}

Não é novidade a atenção dispensada, nos últimos anos, ao debate sobre o tema do desenvolvimento nas Ciências Sociais. Conforme nos apresenta Lima (2013), ao citar autores como Deepar Nayyar e Ignacy Sachs, é possível encontrar notas históricas situando as primeiras discussões ainda durante a Segunda Grande Guerra, notadamente, relativas à reconstrução da Europa. Não obstante, a "[...] noção de desenvolvimento aparece no horizonte da economia e da política e no campo das práticas dos atores políticos e institucionais no Pós-Segunda Guerra." (IVO, 2012, p. 187) Campos (2013, p. 113) afirma ainda que a "[...] ideia de desenvolvimento como progresso, um 'estar atualizado' e capaz de acompanhar o que se considera mais avançado, é tão velha quanto a modernidade [...]". Destarte, para ele, a ideia de desenvolvimento já estava presente no pensamento clássico das Ciências Sociais. 
Sobre a concepção de desenvolvimento que predomina no período da Guerra Fria, mais especificamente entre as décadas de 1950 e 1960, Leher (2012, p. 7) destaca que, houve a defesa da conexão "[...] entre a tecnociência e o arranque econômico rumo ao desenvolvimento [...]", apoiada pelo Departamento de Estado dos Estados Unidos por meio da Agência dos Estados Unidos para o Desenvolvimento Internacional (USAID). Nesse mesmo período, o Banco Mundial tornou-se um protagonista nos estudos sobre o desenvolvimento, e em consonância com as grandes fundações privadas, a exemplo da Ford, John M. Olin, Rockefeller e W. K. Kellog que "[...] influenciaram a agenda e os métodos das ciências [...]". (LEHER, 2012, p. 8)

No caso do Brasil, o debate voltou-se para os desafios do "subdesenvolvimento", nos termos de Celso Furtado e Florestan Fernandes, para citar alguns autores de referência sobre o tema entre as décadas de 1950 e 1970, no bojo das discussões sobre o projeto nacional-desenvolvimentista, como ressalta Ivo (2012), período em que o tema do desenvolvimento ganha centralidade nas Ciências Sociais do Brasil e da América Latina. (RAMALHO; OLIVEIRA, 2013, p. 211)

Ainda para apresentar o debate sobre o desenvolvimento no Brasil, recorremos a Ivo (2012), que recupera autores como Gilberto Freire e Sérgio Buarque de Holanda, dos quais destaca elementos sobre os fundamentos da sociedade brasileira, notadamente, a relação entre a tradição e a modernidade. E, nessa perspectiva, a autora destaca a escola paulista "[...] liderada por Florestan Fernandes e alguns dos seus discípulos: Fernando Henrique Cardoso, Otávio Ianni, Maria Silva de Carvalho Franco, entre outros". (IVO, 2012, p. 189) Esses autores também fizeram a crítica a teses sobre desenvolvimento sustentadas pelos intelectuais do Instituto Superior de Estudos Brasileiros (ISEB) e da Comissão Econômica para a América Latina e o Caribe (CEPAL). (IVO, 2012, p. 189)

Para Leher (2012, p. 12), com

[...] os trabalhos de Florestan Fernandes e Miriam Limoeiro Cardoso, as críticas ao desenvolvimento ganharam consistência. Contudo, tal crítica colidia di- 
retamente com as ideologias operadas pela ditadura. Para silenciá-la a ditadura cassou ambos os professores, bem como outros que trabalhavam na perspectiva crítica do desenvolvimento, como Ruy Mauro Marini. Desse modo a crítica ao desenvolvimento permaneceu em estado de latência nos subterrâneos do pensamento social brasileiro, inclusive após a dita redemocratização.

Sem desconsiderar a variedade de teses e de posições políticas sobre os fundamentos e estratégias do desenvolvimento, Nogueira (2013, p. 117) lembra, remetendo ao livro de Karl Polanyi, A grande transformação, que "[...] o desenvolvimento tornou-se problema categoricamente político. Passou a depender de intervenção estatal, de planejamento, de política organizada. Celebrou-se, assim, a associação entre Estado e desenvolvimento - um não podendo existir sem o outro." E nessa direção, também segundo Nogueira (2013), houve a articulação entre o crescimento econômico e o bem-estar social, configurando, assim, o que denominou de versões mais bem-sucedidas do desenvolvimento no pós-Segunda Grande Guerra. Acrescenta o autor que, em outras versões, como no caso do Brasil entre 1968 e 1978, em que não houve a referida articulação, o crescimento econômico não trouxe melhorias das condições de vida para a população.

Nas décadas 80 e 90 do século XX, destacamos o fortalecimento de posição contrária às conclusões de Polanyi, com o estabelecimento do neoliberalismo, como afirma Bresser Pereira (2004) em texto considerado um dos marcos da retomada do debate sobre o desenvolvimento no Brasil, já no Século XXI.

O nacional-desenvolvimentismo foi a estratégia que regeu o desenvolvimento do Brasil entre 1930 e 1980 um período de enorme crescimento e transformação da economia brasileira. A crise dos anos 80 , porém, coincidiu com o início da onda ideológica globalista e neoliberal que vinha do Norte, e facilitou sua penetração no Brasil. Em 1986, com o Plano Baker, de 1986, a ortodoxia convencional foi transformada em 'estra- 
tégia de desenvolvimento' definida pelo governo dos Estados Unidos e suas agências.

Tomando como marco inicial a crise de 1974-1975 - identificada como a primeira recessão generalizada da economia capitalista internacional desde a Segunda Guerra Mundial -, Netto (1996) recorre ao termo de Mandel, capitalismo tardio, para apresentar uma síntese das transformações societárias que marcaram o período do neoliberalismo, notadamente entre os meados da década de 1970 e da década de 1990. Refere-se ele ao estabelecimento do regime de acumulação flexível, assumindo a designação de Harvey para caracterizar um período de grandes transformações que comportam, entre outros fenômenos, a hipertrofia das atividades de natureza financeira, dotadas de mobilidade espaço temporal e com autonomia em relação aos controles estatais nacionais; a produção segmentada, horizontalizada e descentralizada; e o redesenho do mapa político econômico do mundo.

Ainda de acordo com Netto (1996), tais transformações em estreita relação com a revolução informacional, alteram o cenário mundial em muitos sentidos. A economia de trabalho vivo e a incorporação de novos padrões de gestão da força de trabalho, assim como as alterações significativas no perfil demográfico, conformam um contexto no qual o debate sobre o desenvolvimento foi substituído pelo ideário das políticas de ajuste fiscal, cujo marco inicial foi o Consenso de Washington. E, conforme Ramalho e Oliveira (2013, p. 211), na "[...] virada dos anos 1990 [...] os impactos sociais da globalização econômica e das políticas neoliberais se fizeram sentir nas sociedades latino-americanas."

Nesse processo, de acordo com Boschi e Gaitán (2013, p. 325), o tema do desenvolvimento ressurge sob a designação do neodesenvolvimentismo, "[...] conceito este utilizado como referência à nova leva de estudos sobre o desenvolvimento, posteriores à hegemonia neoliberal." Os autores afirmam ainda que, diante do fracasso das políticas neoliberais, emergem novas vertentes, a exemplo da liderada por Bresser Pereira, ${ }^{3}$ que retoma o estruturalismo cepalino, manten- 
do a importância da intervenção estatal, mas recusando a proteção e o fechamento das economias nacionais. O Instituto de Economia da Universidade Federal do Rio de Janeiro, o Instituto de Pesquisa Econômica Aplicada (Ipea) e a "segunda geração" da Escola de Campinas (Unicamp) são também identificados como protagonistas do debate sobre o neodesenvolvimentismo, que pode ainda ser definido como a "[...] recuperação dos estudos sobre desenvolvimento nas condições de globalização financeira e fragmentação das cadeias de valor herdadas do período neoclássico." (BOSCHI; GAITÁN, 2013, p. 328)

Vale ressaltar, no entanto, a existência de discordâncias em relação à retomada do debate desenvolvimentista pelo neodesenvolvimentismo, posição defendida, por exemplo, por Plínio de Arruda Sampaio Jr. (2012), que nega o caráter de continuidade entre as referidas discussões, alegando haver oposição entre os ideários que orientam os respectivos posicionamentos. Para ele, o neodesenvolvimentismo abandona a questão da autonomia nacional e o problema da integração social.

Consideramos, aqui, que as discussões mais recentes sobre desenvolvimento, tanto na perspectiva do neodesenvolvimentismo como na do desenvolvimento humano, de modo algum estão desconectadas. Na sequência, serão apresentadas algumas notas históricas e conceituais a respeito da gênese e das principais concepções sobre o paradigma do desenvolvimento humano.

No âmbito da Organização das Nações Unidas, além do Banco Mundial e da CEPAL, existem muitas agências que, direta ou indiretamente, estão ligadas a questões do desenvolvimento. Entretanto, o Programa das Nações Unidas (PNUD) ${ }^{4}$ tem um papel central na formulação e difusão de concepções sobre o referido debate, que ganhou relevância incontestável, coetaneamente ao debate sobre o neodesenvolvimentismo, mais precisamente a partir de 1990, com destaque para as análises contidas nos Relatórios de Desenvolvimento Humano (RDHs) e o estabelecimento do Índice de Desenvolvimento Humano (IDH). (MACHADO; PAMPLONA, 2008) 
Ainda em relação às iniciativas e agências da ONU, por outro ângulo, lembramos que tanto as metas estabelecidas nos Objetivos do Milênio ${ }^{5}$ como os índices e conceitos relacionados ao desenvolvimento social e humano, articulados ao crescimento econômico, integram, por assim dizer, os discursos políticos e acadêmicos identificados com o novo desenvolvimentismo e, segundo Maranhão (2012, p. 78, grifos do autor), se afirmam distantes "[...] tanto do fundamentalismo do Consenso de Washington, como também daquilo que chamam de velha concepção desenvolvimentista [...]".

Uma base crucial à perspectiva desse novo projeto de desenvolvimento sustentada pela ONU consiste na concepção de desenvolvimento como liberdade, defendida por Amartya Sen, prêmio Nobel de Economia em 1998. Afirma o economista indiano que "As liberdades não são apenas os fins primordiais do desenvolvimento, mas também os meios principais." (SEN, 2010, p. 25) O esforço voltou-se para a articulação da noção de crescimento econômico com outras dimensões da vida, o que inclui, numa perspectiva instrumental, nos termos do autor, cinco tipos de liberdade: liberdades políticas, facilidades econômicas, oportunidades sociais, garantias de transparência e segurança protetora. A ênfase nas liberdades como condição e produto do desenvolvimento conecta essas noções à ideia de capacidades, pois as liberdades permitem a formação das capacidades e essas últimas, por sua vez, têm como finalidade o alcance e(ou) reforço das liberdades, ao tempo que a ausência de liberdades prejudica o desenvolvimento das capacidades, em um ciclo sem saída.

Destarte, afirmam Machado e Pamplona (2008, p. 69), Sen busca superar os limites apresentados pelo utilitarismo clássico e pelo utilitarismo moderno, pois, de sua perspectiva, "[...] os bens poderiam ser vistos em termos de suas características. Tais características seriam suas propriedades 'desejáveis'. Dessa maneira, ao possuir tais bens, as pessoas passariam a 'comandar' tais características." Os autores ainda ressaltam que, na proposição do economista indiano, o "[...] que muda é o que as pessoas são capazes de fazer a partir dos bens e de suas características." 
Por outro ângulo, conforme Maranhão (2012), ao citar as análises de Macherson, a concepção de desenvolvimento humano de Sen pauta-se na defesa da liberdade de mercado, com a presença de políticas públicas focalizadas e pontuais visando ao bem-estar, que, adequadamente, deve ser destinado a favorecer o acesso ao mercado naturalizado dos indivíduos supervalorizados.

Sobre tal perspectiva endossamos o reconhecimento do que Maranhão (2012) denominou movimento paradoxal, ao se referir, por exemplo, ao não alcance das tímidas metas definidas nos Objetivos do Milênio, que deveriam ter sido cumpridas até 2015.

Mas mesmo não obtendo grandes resultados na execução de seus compromissos, as proposições ideopolíticas defendidas por Amartya Sen e propagandeadas pelos organismos multilaterais têm logrado êxito ao hegemonizarem o debate [...]. Atualmente conceitos como desenvolvimento humano, empoderamento, capital humano, empreendedorismo, entre outros, passaram a dominar o debate sobre planejamento, execução e avaliação das políticas sociais. (MARANHÃO, 2012, p. 102)

Nesses termos, o ideário proposto por Sen foi incorporado pela ONU, notadamente pelo PNUD, como já foi enfatizado, tanto pela mediação das análises vinculadas ao IDH, como pelos RDHs que reiteram os princípios elementares do pensamento do economista indiano.

$\mathrm{Na}$ segunda página do $\mathrm{RDH}$ publicado muito recentemente (PNUD, 2015, p. 2), encontramos a definição de desenvolvimento humano - uma abordagem abrangente, assim apresentada:

O desenvolvimento humano é um processo que permite alargar o leque de escolhas das pessoas, na medida em que adquirem mais capacidades e gozam de mais oportunidades para as usar. Contudo, o desenvolvimento humano é também um objetivo, pelo que é simultaneamente um processo e um resultado. $\mathrm{O}$ desenvolvimento humano traduz-se na possibilidade real de as pessoas influenciarem os processos que mol- 
dam as suas vidas. Considerando todo este contexto, o crescimento econômico é um meio importante para o desenvolvimento humano, mas não é um fim em si.

Portanto, como afirmam Machado e Pamplona (2008, p. 62), apesar das observações que constam em documentos quanto à não adesão integral da ONU aos princípios e conclusões apresentados nos RDHs, por exemplo, "[...] parece difícil acreditar que o PNUD continuaria a apoiar fortemente os relatórios e a associar seu nome a eles, se a organização não se sentisse fortemente amparada e representada em tais relatórios."

Instigados pela possibilidade de refletir sobre alguns aspectos do conhecimento produzido no Brasil pelas Ciências Sociais, sobre desenvolvimento humano, na próxima seção, apresentaremos a descrição dos diversos usos do termo e algumas considerações sobre proximidades e distinções entre os sentidos identificados e os conceitos presentes tanto na perspectiva de Amartya Sen como do PNUD.

\section{Sobre o desenvolvimento humano na produção das Ciências Sociais}

A produção das Ciências Sociais, no Brasil, faz parte da história do desenvolvimento. Este exercício, como foi anunciado, tem como propósito desenvolver uma breve reflexão sobre uma das dimensões dessa participação na atualidade. Nesse sentido, o objetivo desta seção é apresentar alguns dos usos do termo desenvolvimento humano em parte das publicações com grande visibilidade acadêmica, principalmente para a área da Sociologia, ${ }^{6}$ e refletir sobre eles.

Considerando que a centralidade deste exercício está posta nos referidos usos, que configuram sentidos, foi priorizada a apresentação de um mapeamento ou uma configuração que permite refletir sobre textos como produtos e partícipes do campo das Ciências Sociais no Brasil. Portanto, os focos são o debate e o sujeito coletivo que o determinam, também, a partir da relação com outros campos, neste caso, 
com a atenção dirigida às agências da ONU dedicadas ao tema do desenvolvimento, especialmente o PNUD.

Desse ponto de vista, apoiamo-nos em Bourdieu (2001a), quando afirma que o verdadeiro sujeito da obra científica é o campo científico, pois o conhecimento científico, de modo semelhante aos demais produtos culturais, apenas se torna realidade no campo graças ao qual e contra o qual se realiza. A reflexividade, portanto, é exercida pelas coletividades científicas. (BOURDIEU, 2004a)

Destarte, este trabalho pode também ser identificado como um esforço de retorno reflexivo sobre o ato de conhecer, nos termos do sociólogo francês, que volta sua atenção para lembrar que todo fazer científico é, ao mesmo tempo, prática social marcada pelas peculiaridades de universos específicos, no caso, as Ciências Sociais no Brasil, aqui tomadas como um campo disciplinar ou um espaço social particular que, por sua vez, também está encerrado na ambiguidade escolástica, a qual, ao mesmo tempo em que se faz condição de existência do conhecer, o mutila. Lembramos ainda que escolhas teórico-metodológicas são produto da dinâmica dos campos científicos e gozam de graus diversos de autonomia em relação aos campos dominantes ou outras pressões externas. (BOURDIEU, 2001a)

Em articulação com as reflexões apresentadas, destacamos que Ivo (2015), no texto intitulado Agências multilaterais de desenvolvimento e comunidades epistêmicas, chama a atenção para a relevância da produção e da difusão do conhecimento realizadas pelo Banco Mundial e das agendas propostas pelas agências da ONU dedicadas ao desenvolvimento, afirmando, assim, a impossibilidade de "[...] deixar de considerar a influência dessas agendas sobre o universo do conhecimento produzido pela comunidade científica em todo mundo". (IVO, 2015, p. 144) Nesse sentido, tal afirmação encontra-se em consonância com as análises de Bourdieu (2004a) em relação às pressões externas exercidas sobre os campos científicos e, notadamente, no caso das $\mathrm{Ci}$ ências Sociais, cujo objeto também é objeto do discurso de diversos outros campos a exemplo do político e do jornalístico. ${ }^{7}$ 
Desde a tentação do profetismo ${ }^{8}$ - anunciada como um dos obstáculos epistemológicos ao processo de construção do conhecimento nas Ciências Sociais ainda no final dos anos 1960, até às últimas produções, como no caso de Science de la Science et réflexivité -, Bourdieu (2001b) expressa sua preocupação como esforço por garantir a maior autonomia possível à produção dos campos científicos sob os riscos tanto das pressões exercidas por campos externos como das dinâmicas internas que, por vezes são mais vulneráveis, provocando um baixo grau de refração nas referidas demandas.

Nessa perspectiva, parece importante refletir sobre a própria relevância da produção de conhecimento das agências da ONU voltadas ao desenvolvimento, mencionada por Ivo (2015), considerando que tal produção acaba por estabelecer a necessidade de sua participação no diálogo com as Ciências Sociais. Tal diálogo se expressa também nos diversos usos identificados neste estudo.

Destacamos que, dos 757 textos que compõem o universo desta investigação, apenas vinte $(2,6 \%)$ utilizam o termo desenvolvimento humano. Embora, nesse universo, existam outros textos voltados para temáticas relacionadas ao desenvolvimento, ${ }^{9}$ direta ou indiretamente, por não haver menção ao referido termo, não se constituíram em objeto desta análise. Desse modo, não é possível inferir se, de algum modo, tais textos são ou não influenciados pela concepção de desenvolvimento humano ou se relacionam com ela, tanto na perspectiva de Amartya Sen como de questões e abordagens presentes nas posições defendidas nos documentos vinculados a agências da ONU, notadamente ao PNUD.

Como já foi informado, na seleção das revistas pesquisadas, priorizamos as que explicitamente são vinculadas à área das Ciências Sociais, o que também implicou um universo ligado mais diretamente às universidades e, como consequência, também configurou o perfil de autores. Sobre eles, destacamos a titulação de doutor, relativa ao menos a um dos autores, em todos os textos, e a filiação institucional, que inclui, com exceção de um centro de pesquisa e duas universidades estrangeiras, nove universidades federais, duas universidades católicas 
e três estaduais, além de um instituto federal de ensino superior, o que é muito importante para a pesquisa no Brasil. ${ }^{10}$

Com base nas reflexões sobre os usos encontrados, optamos por esboçar uma caracterização do que havia em comum entre os usos e, não obstante qualquer classificação ser limitada e algo arbitrária, construímos alguns tipos de uso para proceder à sistematização e promover reflexões. Nessa perspectiva, os tipos de usos identificados ou esboçados foram: um primeiro tipo, no qual encontramos o termo desenvolvimento humano relacionado ao IDH, ou ainda por constar no termo $\mathrm{IDH}$, ou relativo a um $\mathrm{RDH}$, ou ainda ao Atlas de Desenvolvimento Humano; um segundo tipo, identificado pelos textos com algum indicativo da não incorporação das perspectivas defendidas pelo PNUD ou por Sen; e um terceiro tipo de uso que, aparentemente, não tem relação direta com a concepção de Amartya Sen ou do PNUD, ao qual denominamos de usos no sentido mais ordinário do termo. Embora tenha sido possível agrupar a maioria dos textos com base nos três tipos de usos, consideramos que três dos textos se diferenciavam de qualquer dos tipos e serão apresentados separadamente, ao final, em um quarto agrupamento identificado como exceções.

Ressaltamos que, como existem algumas nuances que diferenciam também os textos de um mesmo grupo - no sentido de favorecer a explicitação dos critérios adotados para a definição dos tipos de agrupamento, concomitantemente, às informações mais gerais que orientaram a classificação -, faremos uma breve apresentação dos textos e descrições dos referidos usos em articulação com as observações buscando entrelaçar descrições e reflexões. No entanto, devido à variedade de usos, há também diferentes apresentações dos respectivos conteúdos e descrições de usos.

Sobre o grupo a ser aqui destacado inicialmente, que identificamos como o primeiro tipo, nove são os textos, dentre os vinte que foram objeto desta análise, ou seja, quase metade dos artigos incorporam o uso do IDH ou outras informações sociais oriundas de documentos do PNUD, seja para caracterizar o contexto socioeconômico de regiões, cidades ou territórios, ou mesmo como critério para a de- 
finição do universo da investigação. Esses textos versam sobre vários temas, como mulheres, participação, cidadania, juventude, trabalho, segurança pública, sustentabilidade, saúde, cultura, economia ou agricultura, e são marcados, também, por diversas abordagens disciplinares, como Saúde Pública, Geografia, Ciência Ambiental, Antropologia, Demografia, Sociologia e Ciência Política. ${ }^{11}$

No primeiro texto (ÁLVARES, 2014), cujo eixo temático é a formação do eleitor brasileiro, a única menção ao IDH no corpo do texto refere-se ao uso do indicador como um dos fatores que definem uma determinada classificação do Brasil, dentre outros países. Os termos relativos a essa classificação são apresentados entre aspas. O uso do IDH em uma nota incorpora-o à argumentação do próprio artigo. Vale ressaltar que, também na introdução, há uma remissão ao site do PNUD, que consta como referência para respaldar informações sobre os níveis globais dos sistemas democráticos.

Nessa mesma direção, o texto três (PICANÇO, 2015) informa que o IDH das regiões do Brasil é incorporado como um "indicador de contexto (variável independente ou não dependente)" em uma formulação crucial ao artigo, ou seja, como um dos indicadores que compõem o Índice de Trabalho Decente (ITD) para mensurar o Trabalho Decente (TD) entre jovens, índice apresentado pelo artigo. Já no texto quatro (ENGELMANN; MADEIRA, 2015) o termo desenvolvimento humano é utilizado apenas para caracterizar uma das três regiões do Brasil apresentadas no estudo, inclusive sem citar índices numéricos. Mais uma vez, a adoção do conceito está presente de forma muito orgânica, por assim dizer. No texto seis (MUÑOZ, 2016), distinto dos demais por ser uma introdução a um dossiê, portanto, de caráter mais sintético, a referência é ao Relatório de Desenvolvimento Humano publicado em 2013 para respaldar a informação sobre a "ascensão do Sul", ou a melhoria dos indicadores apurados pela ONU nos países do Sul.

No texto nove (AZEVEDO; CIFALI, 2015), no item dedicado a apresentar o contexto pós-neoliberal no Brasil, a utilização do IDH dos municípios brasileiros tem como fonte o Atlas do Desenvolvimento Humano, publicado em 2013 pelo PNUD, e teve como finalidade informar 
sobre o cenário de melhorias das condições de vida no país. Entretanto, ressalta ainda as disparidades regionais que, com base também no IDH, permanecem expressivas no período. Em seguida à apresentação dos indicadores que, por sua vez, aparecem após o GINI do mesmo período, há considerações sobre o crescimento econômico. Nesse caso, o uso do IDH agrega-se a outros indicadores disponíveis para desenhar o panorama sociopolítico brasileiro, que assim é reiterado nos termos supostos nos respectivos índices.

O foco do texto 13 (CHACHAM; JAYME, 2016) incide nas intercessões entre desigualdades de classe e violência de gênero nas experiências de sexualidade de mulheres jovens de diferentes classes, território de moradia e raças, na cidade de Belo Horizonte $(\mathrm{BH})$. Ao explicitar que assume a perspectiva relacional para abordar questões de gênero, o texto afirma também considerar as diversas assimetrias, inclusive entre as próprias mulheres. $\mathrm{O}$ artigo adota ainda a noção de violência para além de espancamentos ou da própria violência sexual, incluindo as formas de dominação e subordinação que, conforme as autoras, estão naturalizadas e invisíveis. Nesse bojo, a menção ao IDH da cidade de Belo Horizonte foi adotada como indicador de pertencimento à classe social da população contemplada no universo da pesquisa. Mais especificamente, com base no IDH de $\mathrm{BH}$, foram identificados os bairros de classe média e alta e os maiores aglomerados de favelas, ou seja, a definição do universo da investigação foi baseada no IDH. No caso, mais uma vez, há o uso dos dados disponíveis, que acabam por incorporar às pesquisas que os utilizam os critérios de desenvolvimento humano assumidos pelo PNUD.

O texto 16 (GALVANESE; FAVARETO, 2014) volta-se para a análise de uma experiência relativa às diretrizes de desenvolvimento regional adotadas em uma área de São Paulo cujos indicadores sociais são os mais baixos do estado. A conclusão central refere-se a que o modelo de desenvolvimento, segundo os autores, hoje centrado em territórios e não mais nos recortes setoriais, como nos anos 1970, não alcança os resultados pretendidos devido à incoerência das instituições em relação às estruturas sociais vigentes em um determinado 
território. A noção de estrutura social é fundamentada na perspectiva de Bourdieu, que define estrutura como a configuração das posições dos agentes de acordo com a posse de capital, determinada também pelas respectivas trajetórias históricas desses agentes e pelas configurações anteriores. O texto apresenta ainda algumas modalidades de desenvolvimento, na perspectiva econômica, com diferentes formas de incorporação da questão ambiental. No caso, o termo desenvolvimento humano aparece em nota que faz referência ao Atlas de Desenvolvimento Humano publicado em 2013, apenas para fundamentar a informação sobre as condições de vida da população da área de estudo.

Inicialmente, o texto 19 (VIDAL; SANTOS, 2016) apresenta as características da agricultura familiar e do agronegócio, afirmando serem eles os dois principais territórios na estrutura agrária brasileira contemporânea. Diversas concepções sobre o sentido de território são explicitadas, e a perspectiva de Rafflestin é privilegiada. Nesse texto, a média do IDH expressa mais uma característica, dentre outras, do município objeto da análise.

O objetivo do texto 20 (ANTUNES, 2015) é colocar em discussão a incidência de ações da saúde pública no quadro de desigualdades sociais, e a conclusão central consiste em que os benefícios dos avanços acabam por favorecer as classes mais altas, o que, muitas vezes, reforça os índices de desigualdade. A citação do termo desenvolvimento humano e, explicitamente, do IDH ocorre em três trechos nos quais foram também citados outros indicadores em arranjos relativamente distintos, compondo configurações que explicitam as condições de vida das populações contempladas no estudo.

Esse primeiro grupo, como já foi antecipado, parece aderir aos pressupostos e à concepção do PNUD, em decorrência da incorporação de seus indicadores e análises. Vale salientar que o próprio site do PNUD (2016) informa alguns dos limites do IDH, a exemplo da não avaliação de fatores como a democracia, a participação, a equidade e a sustentabilidade, embora destaque que ele significa um avanço em relação ao uso exclusivo do fator renda calculado com base no PIB 
per capita. Lembramos aqui a relevância desses mesmos fatores para a perspectiva de Sen (2010). Essa mesma fonte ainda informa que, em 2010, houve a incorporação de indicadores complementares, o IDH de Gênero e o Índice de Pobreza Multidimensional, além do Índice de Desenvolvimento Humano Ajustado à Desigualdade (IDHA). Esse último incluiu a desigualdade nos cálculos, ou melhor, incluiu o "desconto" da desigualdade nas três dimensões avaliadas (saúde, educação e renda), e o próprio PNUD refere-se ao IDH como indicador de "potencial", porque indicador de possibilidades. Nas palavras do PNUD (2016): "Com a introdução do IDHAD, o IDH tradicional pode ser visto como um índice de desenvolvimento humano 'potencial' e o IDHAD como um índice do desenvolvimento humano 'real'".

O segundo grupo, identificado pelos textos com algum indicativo de não incorporação das perspectivas defendidas pelo PNUD e(ou) por Sen (2010, é integrado por apenas dois artigos marcados por sutilezas, como veremos a seguir.

O texto oito (BERTAUX, 2014) contrapõe-se à Sociologia que denomina de adepta à "ilusão cientificista", que, segundo o autor, é sustentada por Bourdieu que, por sua vez, perpetua as perspectivas de Comte e Durkheim, e defende uma Sociologia nos termos próximos a Max Weber, segundo o autor. Do ponto de vista desse artigo, as análises de ações individuais livres devem ser priorizadas com base no conceito de curso da ação, ou "[...] a sequência ordenada de ações que uma mesma pessoa executa na durée, para, por exemplo, tentar realizar um de seus projetos [...] ou para defender energicamente uma convicção profunda [...]". (BERTAUX, 2014, p. 255) O termo desenvolvimento humano aparece em uma nota destinada, justamente, a informar sua recusa, além da opção do autor pelo uso do termo "desenvolvimento 'antropônico'", referente ao neologismo por ele mesmo criado e designado pela palavra "antroponomia", que significa "[...] 'a produção das próprias pessoas' [...], de seus corpos pelo consumo, as curas médicas e o care propriamente dito, de seu espírito pelas instituições educativas e as atividades culturais". (BERTAUX, 2014, p. 257) Portanto, embora talvez não tão distante da supervalorização do indivíduo, característi- 
ca atribuída à concepção de Amartya Sen por Maranhão (2012), não dialoga diretamente com as discussões do desenvolvimento aqui elencadas.

O segundo texto destacado pela não incorporação do conceito, o texto dez (GOHN, 2015), tem como objetivo a apresentação de um panorama dos movimentos sociais latino-americanos na atualidade. Ressaltando a distinção do cenário sociopolítico contemporâneo da região em relação ao Século XX, afirma a autora que:

No geral persistem contradições históricas de um processo onde coexiste crescimento econômico em algumas áreas/produtos, integração regional à economia globalizada neoliberal - incentivando-se o ingresso de novos capitais estrangeiros, desindustrialização e transformação da base produtiva industrial nacional - que se voltam para a importação/exportação, incentivo ao consumo de massa, num mundo de mercadorias baratas, abundantes e de baixa qualidade. (GOHN, 2015, p. 492)

Os pontos comuns entre os Séculos XX e XXI, na América Latina, "[...] são: desigualdades sociais e injustiça social em todos os países [...]". (GOHN, 2015, p. 492) O artigo apresenta diversos movimentos sociais ativos na primeira década do Século XXI, notadamente, na Argentina, no Brasil e na Bolívia, com destaque tanto para novas organizações como para as articulações entre elas. A explanação é rica em experiências e instigante nas análises, ressaltando o vigor de ações e organizações coletivas que se colocam no cenário sociopolítico, econômico e cultural de seus países e, também, em espaços e redes internacionais, a exemplo dos movimentos étnicos na Bolívia e Equador; o movimento popular urbano de bairros, no México e na Argentina; o fenômeno da ampliação das fronteiras dos movimentos rurais e do Fórum Social Mundial. Das experiências expostas, destacamos o caráter coletivo dos atores, ações, organizações, lutas e (ou) movimentos. Nas palavras da autora: "Todos estes movimentos têm eclodido na cena pública como 
agentes de novos conflitos e renovação das lutas sociais coletivas." (GOHN, 2015, p. 493)

Nesse sentido, parece interessante refletir sobre o uso do termo desenvolvimento humano nesse artigo, que é usado para qualificar uma das experiências apresentadas. Vale ressaltar que não há menção a Amartya Sen ou qualquer outra referência diretamente ligada às agências da ONU, mas chama a atenção o uso da expressão desenvolvimento humano para qualificar uma concepção de desenvolvimento, que, segundo a autora, constitui o eixo articulatório da abordagem do vivirbien, ou Suma Kumana, presente nas novas constituições da Bolívia e do Equador, "[...] que enfatiza o indivíduo e a qualidade de vida [...]". O texto afirma que tal abordagem é "[...] denominada por alguns como 'desenvolvimento humano integral e sustentável'". E continua qualificando a referida perspectiva de desenvolvimento: "O progresso seria obtido quando os indivíduos têm controle sobre suas vidas, quando atuam sobre suas condições de vida." (GOHN, 2015, p. 498)

A referência, apenas apontada no texto, por sua vez, é a um texto de Catherine Walsh (2010, p. 9, tradução nossa), ${ }_{1}^{12}$ cuja apresentação ressalta justamente o risco de que o bienvivir seja "[...] interpretado também a partir de visões de desenvolvimento ocidentais, com uma consequente perda de sua força radical original."13

Portanto, destacamos a vagueza da indicação no texto, considerando a não explicitação do sentido ou significado do conceito mencionado e, ao mesmo tempo, a sugestiva atenção, por assim dizer, que consta na apresentação do texto de referência. Este sim parece ter como centralidade a preocupação de que não haja confusão entre a perspectiva do bienvivir com o paradigma do desenvolvimento humano conforme o PNUD ou SEN.

Os textos agrupados com base no que denominamos de terceiro tipo apresentam sentidos mais próximos a usos ordinários, e, assim, são mais dependentes das temáticas e das abordagens disciplinares nos quais estão inseridos.

Iniciamos com o texto dois (RODRIGUES; GUIMARÃES, 2016), que se dedica a apresentar uma pesquisa sobre a participação das 
mulheres servidoras públicas na Fundação Oswaldo Cruz, no período de 1996 a 2013. Identificado como um estudo sobre gênero e produção científica, em sua introdução, afirma-se que as "[...] assimetrias de gênero passaram a fazer parte da agenda política de diversas sociedades [...] (RODRIGUES; GUIMARÃES, 2016, p. 199), e que, no caso do Brasil, essa presença provavelmente foi fortalecida pelo "[...] compromisso assumido com as Metas do Milênio", lembrando que a terceira meta, pactuada na Assembleia da ONU, consiste na "promoção da igualdade entre os gêneros e o empoderamento das muIheres". (RODRIGUES; GUIMARÃES, 2016, p. 199, nota 02) Ao apresentar alguns estudos sobre desigualdades entre homens e mulheres na produção científica, utiliza a noção de desenvolvimento humano na definição da "equidade de gênero" adotada no estudo, cuja referência é um relatório do Fórum Econômico Mundial de 2005. O termo desenvolvimento humano aparece compondo o conceito de equidade de gênero em uma nota de rodapé, definição que pode também ser compreendida como uma dimensão desse mesmo conceito: "Equidade de gênero se refere ao estágio de desenvolvimento humano no qual direitos, responsabilidades e oportunidades de indivíduos não serão determinados pelo fato de que indivíduos de diferentes sociedades tenham nascido homem ou mulher." (Fórum Econômico Mundial, 2005 apud RODRIGUES; GUIMARÃES, 2016, p. 203 , nota 05) Ainda assim, mesmo com aparente proximidade com as perspectivas do PNUD e de Sen, consideramos mais um uso sem um sentido determinado.

No texto 11 (MIGLIEVICH-RIBEIRO; ROMERA JUNIOR, 2015), o uso do termo desenvolvimento humano não tem ligação direta com o conceito de Amartya Sen ou dos órgãos da ONU. No caso, refere-se à qualificação da perspectiva de desenvolvimento de Darcy Ribeiro. Notadamente, destina-se a designar o campo para o qual se volta o esforço de Ribeiro, relacionado ao propósito de estabelecer um ponto de vista que orientasse os estudos da formação dos povos americanos e, neles, o Brasil. O humano, então, refere-se à pertinência à humanidade 
e a seu processo "evolutivo" nos termos da crítica ao evolucionismo e da defesa do multievolucionismo.

Acrescentamos, ainda, que o uso do termo desenvolvimento humano no texto 11, embora sustente, de algum modo, uma perspectiva de desenvolvimento - aqui mais próximo do debate desenvolvimentista, considerando que Darcy Ribeiro é um ator relevante tanto do próprio debate como de experiências do "desenvolvimento", tal qual engendrado no pós-guerra -, não constitui exatamente um conceito no sentido de uma definição ou concepção de desenvolvimento. E assim, tal uso aparentemente é alheio ao conceito tal como foi formulado por Sen ou pela ONU.

O texto 12 (HONNETH, 2015) tem como objetivo discutir a possibilidade de desvelar o conceito de "patologias sociais" com base em autores como Alexander Mitscherlich e Sigmund Freud. Uma das inquietações em torno da qual o texto se desenvolve é o caráter impreciso do que significa o termo social nessa equação conceitual. Ao recuperar a história, destaca que, desde Platão, utiliza-se a expressão sociedade doente ou patológica, passando por Rousseau, bem como por Freud e Sartre, que se referem à neurose social ou coletiva, e Durkheim, que trata de anomia ou patologia (disfuncionalidade) social. Além dos expoentes da literatura também citados, a discussão mantém-se vaga ao remeter a muitos sentidos de social. E, embora o autor esteja convencido da possibilidade de falar de uma patologia social, ele afirma que, desde o início, "[...] esta ideia, ademais, traz em si uma grande dificuldade por não estar efetivamente claro quem a rigor estaria enfermo [...]". (HONNETH, 2015, p. 577) Nas páginas finais do texto ao tratar do ponto de vista de Mitscherlich, o autor usa o termo desenvolvimento humano para referir-se ao mesmo fenômeno social, descrito na mesma página, anteriormente, como "[...] desenvolvimento individual da personalidade ou necessário para o enfrentamento dos novos desafios [...]". (HONNETH, 2015, p. 588) Também aqui o uso do termo não tem relação direta, mas poderia ser relacionado às perspectivas de Sen ou da ONU, pela ênfase no indivíduo, ao mesmo tempo em que 
sugere não constituir propriamente um conceito. Ou seja, desenvolvimento é apresentado como sinônimo de processo evolutivo, designando algo relativo ao crescer e ao progredir dos homens, no sentido mais ordinário.

O texto 15 (ADERALDO; RAPOSO, 2016) dedica-se às alternativas de "trocas econômicas e simbólicas" proporcionadas pelos meios digitais aos grupos jovens das periferias de Lisboa e São Paulo. Destacamos, aqui, a defesa de uma noção de território na perspectiva relacional. Em uma citação indireta da concepção de Abélès, Aderaldo e Raposo (2016, p. 281) afirmam que:

[...] é possível dizermos que a maior interconexão global possibilitou que músicas, costumes e estilos de vida atravessassem fronteiras numa velocidade nunca antes vista. A expansão dessa circulação de símbolos por circuitos transnacionais, porém, não implica uma homogeneização cultural, tampouco a perda dos sentidos locais, considerando-se que os mesmos não existem fora dos ambientes onde são consumidos [...].

Nesse estudo, o termo desenvolvimento humano é utilizado em um sentido não diretamente relativo aos conceitos formulados por Sen ou pelo PNUD, porque é estritamente relativo às fases da vida de uma pessoa no trecho no qual o conceito de juventude é tratado. Os autores defendem que tal definição "[...] não deve ser confundida com uma essência ou condição natural e universal do desenvolvimento humano [...]". (ADERALDO; RAPOSO, 2016, p. 282)

O texto 17 (ALMEIDA; WIGGERS, 2014) articula conhecimentos das Ciências Sociais e Humanas, notadamente a sociologia do corpo em diálogo com a área da educação física, com o propósito de refletir sobre as relações do corpo com os processos tecnológicos. Para tanto, recupera as concepções sobre o corpo na história. O uso do termo desenvolvimento humano refere-se, mais uma vez, a um sentido muito genérico, como um processo histórico e natural decorrente da passagem do tempo. 
O último texto desse grupo, o número 18 (VACCARO, 2015), apresenta uma investigação teórica sobre a categoria trabalho nas principais obras de Marx, em confronto com o sentido atribuído à referida categoria por Hannah Arendt, no livro de intitulado A Condição Humana. Nesse caso, o termo desenvolvimento humano aparece em uma citação na qual é explicitado o sentido adotado e que expressa uma perspectiva genérica: "Visto que a meta do desenvolvimento humano é a do desenvolvimento do homem total e universal, o homem tem de ser emancipado da influência mutiladora da especialização (Fromm: 1970, p. 48)."

Os três últimos textos a serem apresentados são as referidas exceções, porque não poderiam ser enquadradas nos tipos definidos. No texto cinco (SERRA; VOLPINI, 2016), voltado para discutir o conceito de vulnerabilidade e explicar a concepção de violência fria para tratar do que denomina vulnerabilidade política, apesar de haver apenas uma citação do termo e entre aspas, destacando por assim dizer os sentidos já instituídos, a concepção de Amartya Sen parece mais evidente embora não explícita pelos autores, considerando a conexão estabelecida entre liberdade política e desenvolvimento humano, ao afirmar que sem a "[...] capacidade de a população em estudo deliberar sobre o próprio destino [...], torna-se impossível falar em um bom nível de desenvolvimento humano".

O texto 14 (SILVA, 2016) tem como propósito apresentar uma análise das "[...] práticas de gestão de pessoas, recursos e rituais por parte das agências de governo de Timor Leste [...]". (SILVA, 2016, p. 127) Tal análise conclui que as referidas agências têm como objetivo a desvalorização da agência de "palavras, objetos e rituais", ao buscar transformar os recursos destinados às práticas relativas às dádivas em mercadorias. As iniciativas do Estado, voltadas, por vezes, à instituição de novas moralidades, valem-se dos próprios complexos locais de governança, como, por exemplo, o Tara Bandu em Ermera, um caso analisado no texto. Notadamente, o artigo apenas informa que o baixo IDH foi apresentado pelo Estado do Timor Leste como justificativa para o uso do Tara Bandu, com o objetivo de estabelecer regras para o 
aproveitamento dos recursos destinados às práticas rituais em recursos para melhorar as condições de vida da população. Desse modo, não houve adoção da concepção ou do próprio indicador na argumentação desenvolvida no artigo.

A terceira exceção exige mais atenção pelos diversos usos ao longo do artigo. A participação do Brasil na cooperação internacional para o desenvolvimento nas áreas de agricultura e alimentação constitui o tema central do texto sete. (MUÑOZ; CARVALHO, 2015) As tensões decorrentes do que caracteriza a presença do Brasil nessas áreas, o sucesso de programas sociais relacionados ao direito à alimentação e o agronegócio constituem focos das reflexões desenvolvidas. Sobre essas tensões, afirma-se que "a alimentação é, assim, ao mesmo tempo, um direito básico que deve ser garantido e protegido, e uma mercadoria." (MUÑOZ; CARVALHO, 2015, p. 33) O artigo também informa que, na última década, houve a diversificação da política externa brasileira, com destaque para a ampla inclusão da África, tanto no aumento do número de embaixadas como da extensão das relações comerciais. Nesse processo, as três principais áreas de atuação do Brasil na Cooperação Sul-Sul (CSS), que são a saúde, a educação e a alimentação, também foram ampliadas.

Consideramos que a primeira remissão ao desenvolvimento humano aparece sem o uso do termo, ao ser feita uma referência à perspectiva de Amartya Sen como um de três modelos de desenvolvimento, no caso, em contraponto aos modelos identificados como um pertinente ao "setor privado" em consonância com "as teorias da modernização" e o outro "[...] baseado nos Direitos Humanos do Programa de Nações Unidas para o Desenvolvimento [...]". (MUÑOZ; CARVALHO, 2015, p. 34) Apresenta, assim, os três modelos como distintos entre si, com destaque para a diferenciação entre a perspectiva de Amartya Sen e a do PNUD, sobre o que não tece mais considerações. Também não há, ao menos de uma maneira mais direta, a adesão a um dos modelos de desenvolvimento explicitados.

$\mathrm{Na}$ segunda incidência do termo, o artigo sete afirma ser a alimentação um direito humano básico e "[...] elemento essencial do de- 
senvolvimento humano e, portanto, também dos projetos de cooperação". (MUÑOZ; CARVALHO, 2015, p. 34) Nesse uso, uma concepção mais genérica vem à tona e, assim, parece sugerir um sentido comum a ser compreendido sem necessidade de definições, o que está presente também na terceira incidência do termo:

O tom dos artigos citados nos dá uma primeira pista: o setor privado - e, dentro dele, as empresas do agronegócio - parece ser o impulsionador da nova fase de esperança em um continente que ainda enfrenta grandes desafios em termos de desenvolvimento humano, em dimensões tão básicas como a alimentação. (MUÑOZ; CARVALHO, 2015, p. 40)

Vale ressaltar que todas as referências ao desenvolvimento estão envoltas, por assim dizer, pela questão central que contrapõe interesses do agronegócio aos interesses da cooperação internacional, no caso da alimentação. Desse modo, consideramos possível admitir que a perspectiva de desenvolvimento humano assumida no texto expresse a recusa ao segundo modelo apresentado, ou o modelo empresarial, o que aparece, de maneira mais evidente, nos trechos citados abaixo, que também conformam a quarta e a quinta incidências do uso do termo desenvolvimento humano. Uma apenas integra o nome de um relatório do PNUD e a outra reproduz o sentido mais genérico já mencionado acima, entretanto distinto dos usos definidos como genéricos relativos ao terceiro tipo.

Aliás, enquanto o agronegócio vê com grande interesse a região, para o PNUD, a segurança alimentar se define como a preocupação central do Relatório de Desenvolvimento Humano (PNUD, 2012) [...]. Os casos do ProSavana em Moçambique, os protestos contra a Vale (que já criaram uma rede internacional de atingidos pela Vale), ou contra a Odebrecht, entre outros, mostram os impactos negativos que esses operadores privados estão provocando em termos de desenvolvimento humano. (MUÑOZ; CARVALHO, 2015, p. 41, 46) 
Não obstante considerarmos haver alguma direção na concepção de desenvolvimento humano adotada pelo artigo sete, ou, mais especificamente, haver adesão a um ideal do desenvolvimento que tenha o humano como centralidade, não podemos afirmar a adoção de um dos dois outros modelos citados, ou mesmo de outra concepção alternativa. Até porque encontramos trechos que afirmam, de algum modo, os modelos tanto de Amartya Sen como do PNUD: "Tratar a alimentação como um direito humano implica, como primeira medi$\mathrm{da}$, colocar as pessoas como sujeitos desse direito e, portanto, como protagonistas, no centro dos processos, garantindo sua participação nas diversas etapas de elaboração de políticas públicas[...]. (MUÑOZ; CARVALHO, 2015, p. 47)

\section{Conclusões}

Encontrar a diversidade de usos do termo desenvolvimento humano foi tão interessante quanto perceber que, em última instância, seria possível construir mediações que interpolassem a maioria dos sentidos explícitos ou anunciados neste estudo. Também chama a atenção a presença de muito mais anúncios sutis dos sentidos mobilizados na argumentação dos artigos, por assim dizer, do que de definições conceituais ou informações sobre as referências adotadas. Não obstante, também podemos refletir sobre a forte presença direta ou indireta, das influências do paradigma do desenvolvimento humano defendido pelo PNUD em sua larga e divulgada produção, como já foi ressaltado.

Nessa direção, retomamos Bourdieu (2004b), ${ }^{14}$ ao refletir sobre os campos específicos em relação com o universo maior, e, mais precisamente, com o que ele denomina de campo do poder. Como espaços relativamente autônomos, os campos relacionam-se com as pressões externas de diferentes formas e proporções. Essas diferenças específicas, como no caso dos campos disciplinares, são determinadas tanto pelo significado das produções do campo para os demais campos, como pelo grau de resistência oferecido por cada campo. 
Importa para o autor saber qual a natureza das coações externas, como se expressam e que estratégias os campos engendram para lidar com as forças externas.

A refração ${ }^{15}$ é o termo utilizado por Bourdieu para referir-se à explicitação de uma das formas de resistência às pressões externas, colocada pelos campos. Ele afirma que o efeito de refração será maior quanto maior for o grau de autonomia. Um campo mais autônomo impõe sua lógica específica às referidas pressões, não as respondendo diretamente, nem se conformando às exigências por elas colocadas.

As exigências são respondidas em graus distintos, sempre sob a mediação da lógica dos campos específicos. O grau de refração ou das alterações impostas pelas leis internas do campo às pressões externas é um dos indicadores mais importantes do poder de cada campo, constituindo-se em referência fundamental para a avaliação das respectivas autonomias relativas. No caso da ciência, de acordo com Bourdieu, as exigências externas são postas mais frequentemente por questões políticas e econômicas.

Afirma Bourdieu (1996, p. 246) que os campos sempre "[...] são atravessados pela necessidade dos campos englobantes, a do lucro, econômico ou político [...]", ainda que disponham de alto grau de autonomia. Desse modo, tais tensões invadem esses universos específicos, interferindo em suas lutas internas. Disputas estabelecem-se entre os agentes que defendem mais veementemente a autonomia e os que são mais "vulneráveis" às sujeições externas, ambas carregadas de possíveis compensações econômicas ou simbólicas. Essas diferentes posições dentro do campo, constituidoras também de subcampos, ${ }^{16}$ têm maior ou menor força, a depender da posição que o campo específico ocupe no campo de poder. Os resultados dessas disputas podem também implicar reforço ou arrefecimento da autonomia relativa. ${ }^{17}$

As épocas e as tradições nacionais impõem variações significativas nas autonomias relativas dos campos, pois o capital simbólico acumulado coletivamente, dependendo de seu peso, pode conferir maior ou menor liberdade em sua relação com o campo de poder. 
Recorremos às análises de Bourdieu sobre os campos científicos e a Ivo (2015) ao tratar de agências multilaterais e comunidades epistêmicas nesta conclusão não apenas para suscitar as possibilidades implicadas em um retorno reflexivo sobre a produção das Ciências Sociais, mas também para tratar dos grandes desafios e limites implicados nesse esforço, considerando que, a cada incidência do termo, seria necessário um desdobramento da investigação que, no caso deste trabaIho, não foi possível realizar. Apenas para exemplificar, enfrentamos dificuldade no acesso às fontes dos artigos analisados, que, imaginamos, seriam muito úteis às reflexões sobre os sentidos.

Nesse mesmo sentido, ressaltamos o que Bachelard e Bourdieu, este sob sua influência, denominam de ação polêmica da razão, ou a possibilidade e a necessidade de colocar em questão, permanentemente, os próprios conceitos que orientam o trabalho de pesquisa, posto que, para essa perspectiva, todos os esforços devem ser envidados, com o objetivo de não permitir que o senso comum, no sentido do não pensado, seja incluído nas investigações, mesmo que da própria herança do campo das Ciências Sociais. Não obstante, é importante lembrar as exigências relativas ao respeito e ao estímulo à diversidade de posições, riqueza configurada, inclusive, de forma muito evidente neste estudo.

Quadro 1 - Levantamento da produção sobre Desenvolvimento Humano (DH) em periódicos brasileiros*

\begin{tabular}{|c|c|c|c|c|}
\hline & $\begin{array}{l}\text { Periódicos/ } \\
\text { Link Acesso }\end{array}$ & $\begin{array}{l}\text { Datas do } \\
\text { Acesso }\end{array}$ & $\begin{array}{l}\text { Total de textos } \\
\text { levantados } \\
\text { (Artigos e } \\
\text { Dossiês) }\end{array}$ & $\begin{array}{l}\mathrm{N}^{\circ} \text { de textos } \\
\text { com o termo } \\
\text { IDH }\end{array}$ \\
\hline 1 & $\begin{array}{l}\text { CADERNO CRH } \\
\text { http://www.scielo.br/scielo.php?script=sci_ } \\
\text { issues\&pid=0103-4979\&lng=pt\&nrm=iso }\end{array}$ & $18 / 06 / 16$ & 86 & 05 \\
\hline 2 & $\begin{array}{l}\text { CADERNOS PAGU } \\
\text { http://www.scielo.br/scielo.php?script=sci_ } \\
\text { issues\&pid=0104-8333\&lng=en\&nrm=iso }\end{array}$ & 08 e 09/06/16 & 82 & 02 \\
\hline 3 & $\begin{array}{l}\text { CIVITAS: Revista de Ciências Sociais } \\
\text { http://revistaseletronicas.pucrs.br/ojs/index.php/ } \\
\text { civitas }\end{array}$ & 19 e 20/06/16 & 89 & 06 \\
\hline
\end{tabular}




\begin{tabular}{|c|l|c|c|c|}
\hline 4 & $\begin{array}{l}\text { DADOS } \\
\text { http://www.scielo.br/scielo.php?script=sci_ } \\
\text { serial\&pid=0011-5258\&Ing=en\&nrm=iso }\end{array}$ & $20 / 06 / 16$ & 75 & 0 \\
\hline 5 & $\begin{array}{l}\text { HORIZONTES ANTROPOLÓGICOS } \\
\text { http://www.scielo.br/scielo.php?script=sci_ } \\
\text { issues\&pid=0104-7183\&Ing=en\&nrm=iso }\end{array}$ & $20 / 06 / 16$ & 60 & 02 \\
\hline 6 & $\begin{array}{l}\text { MANA } \\
\text { http://www.scielo.br/scielo.php?script=sci_ } \\
\text { issues\&pid=0104-9313\&Ing=en\&nrm=iso }\end{array}$ & $20 / 06 / 16$ & 35 & 0 \\
\hline 7 & $\begin{array}{l}\text { REVISTA BRASILEIRA DE CIÊNCIAS sOCIAIS } \\
\text { http://www.scielo.br/scielo.php?script=sci_ } \\
\text { issues\&pid=0102-6909\&Ing=en\&nrm=iso }\end{array}$ & 20 e 21/06/16 & 55 & 01 \\
\hline 8 & $\begin{array}{l}\text { REVISTA DE ANTROPOLOGIA } \\
\text { http://www.revistas.usp.br/ra/issue/archive }\end{array}$ & $21 / 06 / 16$ & 69 & 01 \\
\hline 9 & $\begin{array}{l}\text { SOCIEDADE E ESTADO } \\
\text { http://www.scielo.br/scielo.php?script=sci_ } \\
\text { issues\&pid=0102-6992\&Ing=pt\&nrm=iso }\end{array}$ & $21 / 06 / 16$ & 77 & 01 \\
\hline 10 & $\begin{array}{l}\text { SOCIOLOGIAS } \\
\text { http://www.scielo.br/scielo.php?script=sci_ } \\
\text { issues\&pid=1517-4522\&Ing=en\&nrm=iso }\end{array}$ & 21 e 22/06/16 & 65 & 02 \\
\hline 11 & $\begin{array}{l}\text { TEMPO SOCIAL } \\
\text { http://www.scielo.br/scielo.php?script=sci_ } \\
\text { issues\&pid=0103-2070\&Ing=en\&nrm=iso }\end{array}$ & $22 / 06 / 16$ & 64 & 01 \\
\hline
\end{tabular}

Fonte: SciELO. Brasil, 2016 (Elaboração própria)

*Periódicos A1 do Qualis - Capes 2014 - área de Sociologia, que trazem o termo desenvolvimento humano.

\section{Quadro 2 - Textos selecionados}

\begin{tabular}{|l|l|}
\hline TEXTO 01 & $\begin{array}{l}\text { ÁLVARES, Maria Luzia M. Entre eleitoras e elegíveis: as mulheres e a formação do eleitorado } \\
\text { na democracia brasileira -quem vota? quem se candidata?. Cadernos Pagu, Campinas, n. 43, p. } \\
\text { 119-167, jul./dez. 2014. }\end{array}$ \\
\hline TEXTO 02 & $\begin{array}{l}\text { RODRIGUES, Jeorgina G.; GUIMARÃES, Maria Cristina Soares. A Fundação Oswaldo Cruz e } \\
\text { a ciência no feminino: a participação feminina na prática e na gestão da pesquisa em uma } \\
\text { instituição de ensino e pesquisa. Cadernos Pagu, Campinas, n. 46, p. 197-222, jan./abr. } 2016 .\end{array}$ \\
\hline TEXTO 03 & $\begin{array}{l}\text { PICANÇO, Felícia Silva. Juventude e trabalho decente no Brasil - uma proposta de mensuração. } \\
\text { Caderno CRH, Salvador, v. 28, n. 75, p. 569-590, set./dez. 2015. }\end{array}$ \\
\hline TEXTO 04 & $\begin{array}{l}\text { ENGELMANN, Fabiano; MADEIRA, Lígia M. A causa e as políticas de direitos humanos no } \\
\text { Brasil. Caderno CRH, Salvador, v. 28, n. 75, p. 623-637, set./dez. 2015. }\end{array}$ \\
\hline TEXTO 05 & $\begin{array}{l}\text { SERRA, Ordep. VOLPINI, Lorena.Considerações sobre violência fria. Caderno CRH, Salvador, v. } \\
\text { 29, n. 76, p. 119-131, jan./abr. 2016. }\end{array}$ \\
\hline TEXTO 06 & $\begin{array}{l}\text { MUÑOZ, Enara Echart. A cooperação Sul-Sul do Brasil com a África. Caderno CRH. Salvador, v. } \\
\text { 29, n. 76, p. 9-12, jan./abr. 2016. }\end{array}$ \\
\hline TEXTO 07 & $\begin{array}{l}\text { MUÑOZ, Enara Echart; CARVALHO, Tássia Camila de O. A cooperação Sul-Sul brasileira com a } \\
\text { África no campo da alimentação: uma política coerente com o desenvolvimento?Caderno CRH, } \\
\text { Salvador, v. 29, n. 76, p. 33-52, jan./abr. 2016. }\end{array}$ \\
\hline
\end{tabular}




\begin{tabular}{|c|c|}
\hline TEXTO 08 & $\begin{array}{l}\text { BERTAUX, Daniel. A vingança do curso de ação contra a ilusão cientificista. Civitas,Porto Alegre, } \\
\text { v. } 14 \text {, n. 2, p. } 250-271 \text {, maio/ago. } 2014 \text {. }\end{array}$ \\
\hline TEXTO 09 & $\begin{array}{l}\text { AZEVEDO, Rodrigo G. de; CIFALI, Ana Cláudia. Política criminal e encarceramento no Brasil } \\
\text { nos governos Lula e Dilma. Elementos para um balanço de uma experiência de governo pós- } \\
\text { neoliberal. Civitas, Porto Alegre, v. 15, n. 1, p. 105-127, jan./mar. } 2015 \text {. }\end{array}$ \\
\hline TEXTO 10 & $\begin{array}{l}\text { GOHN, Maria da Gloria. Vozes que gritam e vozes silenciadas na América Latina. Civitas, Porto } \\
\text { Alegre, v. } 15 \text {, n. 3, p. 491-509, jul./set. } 2015 \text {. }\end{array}$ \\
\hline TEXTO 11 & $\begin{array}{l}\text { MIGLIEVICH-RIBEIRO, Adelia; ROMERA JUNIOR, Edison. Vozes dissidentes e modernidades } \\
\text { dissonantes na América Latina. Civitas, Porto Alegre, v. 15, n. 3, p. 403-420, jul./set. } 2015 .\end{array}$ \\
\hline TEXTO 12 & $\begin{array}{l}\text { HONNETH, Axel. As enfermidades da sociedade. Aproximação a um conceito quase } \\
\text { impossível. Civitas, Porto Alegre, v. 15, n. 4, p. 575-594, out./dez. } 2015 .\end{array}$ \\
\hline TEXTO 13 & $\begin{array}{l}\text { CHACHAM, Alessandra S.; JAYME, Juliana G. Violência de gênero, desigualdade social e } \\
\text { sexualidade. As experiências de mulheres jovens em Belo Horizonte, Civitas, Porto Alegre, v. 16, } \\
\text { n. 1, e1-e19, jan./mar. } 2016 .\end{array}$ \\
\hline TEXTO 14 & $\begin{array}{l}\text { SILVA, Kelly.Administrando pessoas, recursos e rituais. Pedagogia econômica como tática de } \\
\text { governo em Timor-Leste. Horizonte Antropológico. Porto Alegre, v. 22, n. 45, p. 127-153, } 2016 . \\
\text { Disponível em: <http://dx.doi.org/10.1590/S0104-71832016000100006>. }\end{array}$ \\
\hline TEXTO 15 & $\begin{array}{l}\text { ADERALDO, Guilhermo; RAPOSO, Otávio.Deslocando fronteiras: notas sobre intervenções } \\
\text { estéticas, economia cultural e mobilidade juvenil em áreas periféricas de São Paulo e Lisboa. } \\
\text { Horizonte Antropológico, Porto Alegre, v. 22, n. 45, p. 279-305, 2016. Disponível em: <http:// } \\
\text { dx.doi.org/10.1590/S0104-71832016000100011>. }\end{array}$ \\
\hline TEXTO 16 & $\begin{array}{l}\text { GALVANESE, Carolina; FAVARETO, Arilson.Dilemas do planejamento regional e as instituições } \\
\text { do desenvolvimento sustentável. Revista Brasileira de Ciências Sociais, São Paulo, v.29, n.84, } \\
\text { p.73-86, fev. 2014. Disponível em: <http://dx.doi.org/10.1590/S0102-69092014000100005>. }\end{array}$ \\
\hline TEXTO 17 & $\begin{array}{l}\text { ALMEIDA, Dulce Filgueira de; WIGGERS, Ingrid Dittrich; JUBE, Carolina Nascimento.Do corpo } \\
\text { produtivo ao corpo rascunho: aproximações conceituais a partir de relações entre corpo e } \\
\text { tecnologia. Sociedade \& Estado, Brasília, v.29, n.3, p.963-983, set./dez. 2014. Disponível em: } \\
\text { <http://dx.doi.org/10.1590/S0102-69922014000300014>. }\end{array}$ \\
\hline TEXTO 18 & $\begin{array}{l}\text { VACCARO, Stefania Becattini.Karl Marx e Hannah Arendt: uma confrontação sobre a noção } \\
\text { de trabalho. Sociologias,Porto Alegre, v.17, n. 40, p.358-378, dez. 2015. Disponível em: <http:// } \\
\text { dx.doi.org/10.1590/15174522-017004011>. }\end{array}$ \\
\hline TEXTO 19 & $\begin{array}{l}\text { VIDAL, Déa de Lima; SANTOS, Daniel P. A. Realidade territorial de unidades familiares no } \\
\text { semiárido brasileiro. Tempo Social, São Paulo, v. 28, n. 1, p. 55-83, jan./jun. 2016. Disponível } \\
\text { em: <http://dx.doi.org/10.11606/0103-2070.ts.2016.105992> }\end{array}$ \\
\hline TEXTO 20 & $\begin{array}{l}\text { ANTUNES, José Leopoldo Ferreira. Intervenções em saúde pública e seu impacto nas } \\
\text { desigualdades sociais em saúde. Tempo Social, São Paulo, v. 27, n. 1, p. 161-175, } 2015 . \\
\text { Disponível em: <http://dx.doi.org/10.1590/0103-20702015018>. }\end{array}$ \\
\hline
\end{tabular}

\section{Referências}

BOSCHI, R.; GAITÁN, F. Neodesenvolvimentismo. In: IVO, Anete B. L. et al. Dicionário temático desenvolvimento e questão social. São Paulo: Annablume, 2013. p. 325-329.

BOURDIEU, P.; CHAMBOREDON, J. C.; PASSERON, J. C. A profissão de sociólogo: preliminares epistemológicas. Tradução de Guilherme João de Freitas Teixeira. 2. ed. Petrópolis, RJ: Vozes, 2000. 
BOURDIEU, P. O campo científico. In: ORTIZ, R. (Org.); FERNANDES, F. (Coord.). Pierre Bourdieu. Tradução de Paula Montero e Alícia Auzmendi. São Paulo: Ática, 1983. p. 122-155.

BOURDIEU, P. As regras da arte: gênese e estrutura do campo literário. Tradução de Maria Lúcia Machado. São Paulo: Companhia das Letras, 1996.

BOURDIEU, P. Meditações pascalianas. Tradução de Sérgio Miceli. Rio de Janeiro: Bertrand Brasil, 2001a.

BOURDIEU, P. Science de lascience et réflexivité. (Coursdu Collège de France 2000-2001). Paris: Raisons d'agir, 2001b.

BOURDIEU, P. Para uma sociologia da ciência. Tradução de Pedro Elói Duarte. Lisboa: Edições 70, 2004a.

BOURDIEU, P. Os usos sociais da ciência: por uma sociologia clínica do campo científico; texto revisto pelo autor com a colaboração de Patrick Champagne e Etienne Landais. Tradução de Denice Bárbara Catani. São Paulo: Ed. Unesp, 2004b.

BRESSER PEREIRA, L. C. O novo desenvolvimentismo. Folha de São Paulo, São Paulo, 19 set. 2004. Disponível em: <http://www.bresserpereira.org.br/ articles/2004/412. NovoDesenvolvimentismo.pdf>. Acesso em: 10 jul. 2016.

CAMPOS, R. C. Desenvolvimento e democracia: dilemas e 'trilemas' da modernidade. In: IVO, A. B. L. et al. Dicionário temático desenvolvimento e questão Social. São Paulo: Annablume, 2013. p. 110-116.

CAPES. Coordenação de Aperfeiçoamento de Pessoal de Nível Superior. Disponível em: <https://sucupira.capes.gov.br/sucupira/public/consultas/ coleta/veiculoPublicacaoQualis/listaConsultaGeralPeriodicos.jsf>. Acesso em: 7 maio 2016.

IVO, Anete B. L. O Paradigma do desenvolvimento: do mito fundador ao novo desenvolvimento. Caderno CRH, Salvador, v. 25, n. 65, p. 187-210, maio/ago. 2012.

IVO, Anete B. L. Agências multilaterais de desenvolvimento e comunidades epistêmicas. Cadernos do CEAS, Salvador, n. 235, p. 129-152, jul./dez. 2015.

LEHER, R. Ideologia do desenvolvimento, pobreza e hegemonia. In: MOTA, A. E. (Org.). Desenvolvimentismo e construção de hegemonia. São Paulo: Cortez, 2012.

LIMA, M. C. Desenvolvimento, atualização da noção. In: IVO, Anete B. L. et al. Dicionário temático desenvolvimento e questão Social. São Paulo: Annablume, 2013. p. 93-101. 
MACHADO, J. G. R.; PAMPLONA, J. B. A ONU e o desenvolvimento econômico: uma interpretação das bases teóricas da atuação do PNUD. Economia e Sociedade, Campinas, v. 17, n. 1 (32), p. 53-84, abr. 2008.

MARANHÃO, C. H. Desenvolvimento social como liberdade de mercado: AmatyaSen e a renovação das promessas neoliberais. In: MOTA, A. E. (Org.). Desenvolvimentismo e construção da hegemonia: crescimento econômico e reprodução da desigualdade. São Paulo: Cortez, 2012.

NETTO, J. P. Transformações societárias e serviço social: notas para uma análise prospectiva da profissão no Brasil. Serviço Social e Sociedade, São Paulo, n. 50, p. 87-132, abr. 1996.

NOGUEIRA, M. A. Desenvolvimento e pacto social. In: IVO, Anete B. L. et al. Dicionário temático desenvolvimento e questão Social. São Paulo: Annablume, 2013. p. 116-123.

PINTO, L. Pierre Bourdieu e a teoria do mundo social. Rio de Janeiro: FGV, 2000.

PNUD. Programa das Nações Unidas para o Desenvolvimento. Apresentação. 2016. Disponível em: <http://www.pnud.org.br/>. Acesso em: 26 jul. 2016.

RAMALHO, J. R.; OLIVEIRA, R. V de. A atualidade do debate sobre trabalho e desenvolvimento. (Introdução). Caderno CRH, Salvador, v. 26, n. 68, p. 211215, maio/ago. 2013.

SAMPAIO JR., P. de A. Desenvolvimentismo e neodesenvolvimentismo: tragédia e farsa. Serviço Social e Sociedade, São Paulo, n. 112, p. 672-688, out./dez. 2012.

SEN, A. Desenvolvimento como liberdade. Trad. Laura Teixeira Motta; revisão técnica Ricardo Doninelli Mendes. São Paulo: Companhia das Letras, 2010.

WALSH, C. Desenvolvimento como BuenVivir: arranjos institucionais e laços (des) coloniais. (Editorial). Revista Nuevamerica, n. 126, 2010. Disponível em: <http://www.novamerica.org.br/revista_novamerica/anteriores/r0126/ resumos.asp>. Acesso em: 30 jul. 2016.

\section{Notas explicativas}

1 Esta investigação integra o Projeto "A Reinvenção do Desenvolvimento. Agências multilaterais e produção sociológica contemporânea" (Projeto Universal CNPq. Edital n.14/2012), que analisa as normativas das agências multilaterais sobre a produção sociológica brasileira, nas décadas de 1990-2000, coordenado por Anete B. L. Ivo. O projeto envolve a colaboração de pesquisadoras associadas, que analisam temas selecionados do repertório das agências multilaterais sobre o desenvolvimento e seus efeitos sobre a produção sociológica, na últi- 
ma década: desenvolvimento humano; questão ambiental e seus efeitos sobre povos tradicionais; cooperação internacional; a Agenda Pós-ODM; questão das cidades e a agenda da Habitat (Assentamentos humanos). A articulação desses projetos permite reconstruir novas dimensões da Sociologia do Desenvolvimento contemporânea e observar as tensões entre a escala do desenvolvimento internacional e a agenda da Sociologia brasileira nos anos 1990 a 2014, aprofundando a relação dialética entre ciência e política.

2 Considerando que os propósitos deste estudo se voltam para as Ciências Sociais e, mais especificamente, para a Sociologia, eliminamos da análise as revistas com escopo disciplinar muito abrangente: Lua Nova, História Ciência e Saúde-Manguinhos e Educação e Sociedade. Ressaltamos, ainda, que o uso das versões on-line, mesmo quando apenas a versão impressa esteja classificada como A1, deve-se ao fato de que a não classificação no extrato $A 1$ das versões on-line não interfere nos conteúdos aqui selecionados. Portanto, os fatores que possivelmente determinaram a classificação das versões on-line em outro extrato, ou mesmo a inexistência de classificação, não são relevantes para este trabalho.

3 Luiz Carlos Bresser Pereira, professor da Fundação Getúlio Vargas, foi ministro da Fazenda de José Sarney e ministro da Reforma do Estado no primeiro mandato de Fernando Henrique Cardoso.

4 No site do PNUD (2016), encontramos a seguinte apresentação: "O Programa das Nações Unidas para o Desenvolvimento executa diversos projetos em diferentes áreas. Neles, o PNUD oferece aos parceiros apoio técnico, operacional e gerencial, por meio de acesso a metodologias, conhecimentos, consultoria especializada e ampla rede de cooperação técnica internacional. Com o objetivo de contribuir para o desenvolvimento humano, o combate à pobreza e o crescimento do país nas áreas prioritárias, o PNUD Brasil tem a constante missão de buscar alinhar seus serviços às necessidades de um país dinâmico, multifacetado e diversificado. Os projetos são realizados em parceria com o Governo Brasileiro, instituições financeiras internacionais, setor privado e sociedade civil."

5 De acordo com o site do PNUD (2016), no Brasil, como uma expressão consequente da década de 1990, na qual houve a realização de grandes conferências e eventos da ONU, em 2000 foi firmada a Declaração do Milênio. "Com a Declaração, as Nações se comprometeram a uma nova parceria global para reduzir a pobreza extrema, em uma série de oito objetivos - com um prazo para o seu alcance em 2015 - que se tornaram conhecidos como os Objetivos de Desenvolvimento do Milênio (ODM)." Os referidos objetivos versavam sobre a diminuição da pobreza e da mortalidade infantil; o combate ao HIV/AIDS, à malária e outras doenças; o alcance da universalização do acesso ao ensino básico e da equidade de gênero; além da garantia de sustentabilidade ambiental e da efetivação de uma parceria mundial voltada para o desenvolvimento.

6 A base de consulta deste estudo foi composta de 11 periódicos, e o levantamento ocorreu entre os dias 8 e 22 de junho de 2016. De um total de 757 textos, dos quais foram feitos downloads no momento do acesso, 20 utilizam o termo desenvolvimento humano no corpo do texto ou em notas, identificados pela ferramenta de busca utilizando o termo entre aspas. Não foram consideradas as citações em referências bibliográficas, a exemplo de título de publicações. A relação dos periódicos selecionados encontra-se no Quadro 1.

7 Bourdieu (2001b, p. 168) reconhece "[...] que as ciências sociais são ciências como as outras, mas que têm uma dificuldade particular para serem ciências como as outras", pois são mais vulneráveis às determinações sociais. A Sociologia é ainda mais exposta, por ter como objeto o objeto de disputa da vida social em todos os campos. Tal condição torna as Ciências Sociais mais propensas às interferências externas que as Ciências Naturais. 
8 A tentação do profetismo, relativa à "[...] tarefa de responder às questões últimas sobre o futuro da civilização [...]" (BOURDIEU, 2000, p. 36), por exemplo, refere-se às demandas externas colocadas para a Sociologia e à tentação de respondê-las a que os sociólogos estão sujeitos. Isso implica o risco de trazer, para o universo da ciência, objetos e abordagens não constituídos a partir dele. O duplo jogo profético no uso da linguagem sociológica, sem considerar seu uso no senso comum, também explicita a submissão do discurso sociológico a demandas externas.

9 Apenas para exemplificar, remetemos ao volume 57 da revista Dados, publicado em 2014, e ao volume 20, n. 41 da revista Horizonte Antropológico.

10 As Universidades Federais são do Pará (UFPA), do Rio de Janeiro (UFRJ), UNIRIO, do ABC (UFABC), da Bahia (UFBA); do Rio Grande do Sul (UFRGS), Fluminense (UFF), do Ceará (UFC) e de Brasília (UnB); as estaduais são a Universidade do Estado de São Paulo (USP), do Estado do Ceará (UECE) e do Estado do Rio de Janeiro (UERJ); as católicas são as pontifícias universidades católicas de Minas Gerais e do Rio Grande do Sul. As universidades estrangeiras são a Universidades de Frankfurt na Alemanha e a Universidade de Lisboa em Portugal, além do Centro de Pesquisa, e o instituto de ensino superior é O Instituto de Comunicação e Informação Científica e Tecnológica em Saúde (ICICT), vinculado à Fundação Oswaldo Cruz (FIOCRUZ).

11 Considerando que há uma diversidade de áreas disciplinares vinculadas ao estudo, mesmo apenas considerando a trajetória de formação e filiação institucional dos autores, optamos por explicitar a vinculação institucional atual quando não havia uma indicação direta da área disciplinar no resumo do currículo Lattes.

12 Não foi possível ter acesso ao texto na íntegra, mas essa crítica consta na apresentação do artigo no editorial disponível na página on-line da revista, conforme consta nas referências.

13 Trecho original: "[...] interpretado también a partir de visiones de desarrollo occidentales, con una consecuente perdida de su fuerza radical original." (WALSH, 2010, p. 9)

14 Alguns trechos dessa seção reproduz partes da dissertação de mestrado da autora, Cristiana Mercuri de Almeida Bastos, A sociologia da ciência e a polêmica epistemológica: uma reflexão em Pierre Bourdieu, defendida na Universidade Federal da Bahia, em 2004.

15 O termo, oriundo da física, constitui uma analogia, porque se refere ao fenômeno da alteração sofrida por um raio de luz ao penetrar em um meio diferente.

16 "O grau de autonomia de um campo de produção cultural revela-se no grau em que o princípio de hierarquização externa aí está subordinado ao princípio de hierarquização interna: quanto maior é a autonomia, mais a relação de forças simbólicas é favorável aos produtores mais independentes da demanda e mais o corte tende a acentuar-se entre os dois polos do campo, isto é, entre o subcampo de produção restrita, onde os produtores têm como clientes apenas os outros produtores, que são também seus concorrentes diretos, e o subcampo de grande produção, que se encontra simbolicamente excluído e desacreditado." (BOURDIEU, 1996, p. 246, grifos do autor)

17 Louis Pinto (2000, p. 82) ressalta que é importante "[...] compreender que a autonomia [de um campo] não é uma situação para sempre garantida juridicamente, e sim o resultado de lutas que se inserem na história." 